\title{
СЛУЧАЙ МЕДЛЕННО ПРОГРЕССИРУЮЩЕГО АУТОИММУННОГО САХАРНОГО ДИАБЕТА У РЕБЕНКА С ОЖИРЕНИЕМ
}

\author{
Кураева Т.Л., Сечко Е.А., Еремина И.А., Романенкова Е.М., Татаревич Е.Ю.
}

ФГБУ «Национальный медицинский исследовательский чентр эндокринологии» Минздрава России, Москва

С распространением ожирения в детской популяции все чаще ожирение будет встречаться у пациентов с сахарным диабетом (СД), в том числе с сахарным диабетом 1 типа (СД1). Ожирение модифицирует клиническую картину СД1, приводя к гипердиагностике сахарного диабета 2 типа (СД2) в детском возрасте.

КЛИНИЧЕСКИЙ СЛУЧАЙ: СД У мальчика с 15 лет. Манифестация острая с кетоацидозом, гликемия 25,3 ммоль/л, кетоацидоз, pH 7,0, НbА с 7,9\%. Назначен инсулин 43 ед/ сутки, 0,4 ед/кг/сут (аспарт, деглюдек).

Через 1,5 мес обследован в НМИЦ эндокринологии. Рост 161,5 (SDS -0,75), масса тела 104 кг, ИМТ 39,9 кг/M² (SDS ИМТ 3,63). Подкожно-жировая клетчатка развита избыточна, перераспределена абдоминальному типу, «климактерический горбик», в подмышечных впадинах, на шее acantosis nigricans. $\mathrm{HbA}_{1 c} 6,4 \%$. При проведении перорального глюкозотолерантного теста (ПГТТ) (на фоне инъекции инсулина деглюдек 12 ед) базальная гликемия - 4,89 ммоль/л, на 60 мин - 10,84 ммоль/л, на 120 мин 8,56 ммоль/л. Секреция инсулина, С-пептида сохранная. Базальный уровень инсулина - 19,86 Ед/л, на 60 мин - 72,58 Ед/л, на 120 мин - 92,83 Ед/л. Базальный уровень С-пептида — 2,58 нг/мл, на 60 мин 6,39 нг/мл, на 120 мин - 8,62 нг/мл. Индекс НОМА 4,3 (норма<3,2). Показатели липидного профиля в норме. Диагностирован фокальный стеатоз печени на фоне умеренной гепатомегалии. Инсулин был отменен с сохранением нормогликемии. Учитывая высокий уровень инсулина и С-пептида, наличие ожирения, инсулинорезистентности (ИР), отсутствие потребности в инсулине, диагностирован СД2. Однако после получения высокого титра специфических панкреатических антител (IA2 420,7 Ед/мл (0-10), GAD 5,6 (0-10), ICA 16,8 Ед/л (0-1), ZnT8 710,5 (0-15)), у мальчика верифицирован СД1.

Через 6 месяцев $\mathrm{HbA}_{1 c}$ 6,8\%. Через 11 месяцев $\mathrm{HbA}_{1 c}$ 8,5\%. Назначен инсулин деглюдек 11 ед/сут-

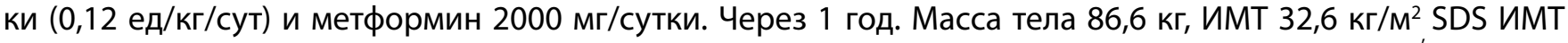
$+2,94$. $\mathrm{HbA}_{1 c} 6,3 \%$. В подмышечных впадинах, на шее acantosis nigricans менее выражен. По данным ПГТТ (терапия отменена) базальная гликемия составил 6,25 ммоль/л, на 60 мин - 14,59 ммоль/л, на 120 мин 13,06 ммоль/л. Базальный уровень инсулина — 20,39 Ед/л, на 60 мин — 57,03 Ед/л, на 120 мин — 54,61 Ед/л. Базальный уровень С-пептида - 2,63 нг/мл, на 60 мин - 5,92 нг/мл, на 120 мин - 6,3 нг/мл. Индекс НОМА 5,8. В связи с сохраняющейся ИР терапия метформином в дозе 2000 в сочетании с инсулином (4 ед, 0,05 ед/кг/сут) была продолжена.

BЫВоды: по рекомендации ISPAD, у подростков с ожирением, несмотря на острую манифестацию, необходимо исключать СД2, для которого характерна ИР, проявляющаяся через 2-3 месяца после диабетического кетоацидоза. В данном случае нами выявлена ИР по индексам ИР и клиническими признаками (acantosis nigricans) через 1,5 месяца от ДКА, что позволило на первом этапе диагностировать СД2. Полученные данные по аутоиммунитету позволили верифицировать СД1. На фоне снижение веса течение диабета остается стабильным, с нормогликемией. Представленный пример демонстрирует меняющееся течение СД1 у пациентов с выраженным ожирением, а также необходимость, кроме выявленной ИР, определения аутоантител у детей с диабетом в сочетании с ожирением для проведения дифференциальной диагностики СД1 и СД2. 